\title{
Study of Physical, Social and Functional Structures in Bagdat Street (Istanbul) as Public Space
}

\author{
Ziba Sami*, M. Ebru Erdonmez Dincer \\ Faculty of Architecture, Yıldiz Technical University, Turkey \\ Received March 13, 2020; Revised April 22, 2020; Accepted May 3, 2020
}

Copyright $\bigcirc 2020$ by authors, all rights reserved. Authors agree that this article remains permanently open access under the terms of the Creative Commons Attribution License 4.0 International License

\begin{abstract}
The increased population density, technological advances and modern communication tools have affected urban design, planning and architecture in urban centers. On the other hand, the disproportionate population growth has caused urban managers not to pay much attention to non-physical aspects of cities and to ignore the mental impacts of urban sprawl on citizens. The street has undergone a variety of changes historically and functionally over time; hence this study aims to assess the physical-functional characteristics and their effect on social relationships on Bagdat Street. This study is an applied research in terms of its objectives and employs a descriptive-analytical methodology. The information is collected through field research (observation, interview and questionnaire). The field data is obtained by distributing the questionnaires. According to the research on green spaces, numerous coastal walking spaces, cafes and shopping malls have had a great influence upon people's social relationships on Bagdat Street, but these social spaces profoundly have affected the relationships of residents in terms of furniture, performance at urban level and physical changes of the street throughout history and even led to problems, which are properly investigated in this study.
\end{abstract}

Keywords Bagdat Street, Public Space, Physical, Social, Functional

\section{Introduction}

Cities are sociocultural constructed phenomena that emerge out of sociocultural practices that are often the reflections of political, economic, social and spatial changes in the society [15].A city, which is a lively and dynamic place, plays an important role in the mental well-being of individuals. Individuals living in the cities need safe, public spaces to get rest from the overwhelming heavy traffic and have fun. Therefore, public spaces are of great importance to urban residents and urban life [19]. Undoubtedly, these urban changes in Istanbul do not only originate from the functions that the city has undertaken [11]. The question on how urban transformation affects the daily lives of those living in the neighborhoods of Bagdat Street is important. Generally, the residents of this street are average and high earners with high literacy.

Bagdat Street is one of the most important streets in Istanbul, which has faced different changes throughout history. Therefore, it is so important to study the social factors in different spaces of this street and its function at urban level. There are various studies about Bagdat Street. Yazicioglu (2012) studied human-environment effect, behavior and its impact on walkable urban and investigated Bagdat Street. Koylan (2018) wrote a thesis on its history and changes through different periods. Erdonmez and Aki (2005) and Berkmen and Turgut (2019) studied the impact of social factors on Bagdat Street and the changes occurred on Bagdat Road. Lotfata (2014) wrote about the impact of changes in urban spaces on socio-cultural relationships, in which Bagdat Street was assessed. There have been already numerous studies on Bagdat Street, but there is no extensive research on the impact of physical factors and functional elements on social relationships, which is the main reason for this study. The research question is about the effect of physical factors and land use on the residents' social relationships in terms of different factors. To carry out this study, the street is initially assessed in terms of importance, concepts of urban spaces and role of beaches. In the second section, the role of these factors in people's social relationships on Bagdat Street is then investigated.

\section{Urban Spaces}

A city is a social - spatial context that we as an individual or group enter into it, and interact with it in order to use or modify it. Architecture and urbanism scientists 
believe that urban space is beyond its physical and geometric components [3].According to Cullen, urban space is the most important place to show up and emphasize the social events [7], Jane Jacobs also emphasizes on the role of urban spaces in creating social interactions and participation [20]. Urban spaces can be considered as a part of open and public urban spaces which reflect the social life. Urban spaces are the realm of human interaction and greatly affect the collective life of human beings. Humans can act in urban spaces; this breaks social boundaries and leads to unpredicted encounters. Francis considered urban spaces as a part of urban fabric which is physically and visually available to the public [6]. Therefore, it is possible to define the task of public spaces as follows:

(1) tools for social relationships

(2) places for citizen encounters

(3) citizen management and coordination.

\section{Street}

Street, as an element which forms the largest portion of public spaces in a city, is of great importance. Since their formation, the streets have been the center of the social, cultural and economic life of cities [13]. The streets have become prominent with communication facilities and social life since the second half of the 20th century to the present day. The highways that serve only vehicle traffic have gained importance as areas that allow people to socialize and bring people together, unlike service roads or any connecting roads [19]. The street is the external space where the urbanite achieves external social and business encounters and changes in the easiest way. The first and most important places of social life are streets [27].

According to Velioglu, urban space is the "urban physical environment fiction" in which people live and the outer spaces in this fiction and their experiences and activities in these fields. The use of the urban space of the city is determined through actions such as movement, shopping, recreation, leisure time and sports activities. However, the most important feature of the urban space is that it reflects social and cultural features [25]. In Table 1 the Meaning of the Street and the Parameters was analyzed:

Table 1. The Meaning of the Street and the Parameters Affecting It

\begin{tabular}{|l|l|}
\hline \multicolumn{1}{|c|}{ Descriptions } & \multicolumn{1}{|c|}{ Parameter } \\
\hline $\begin{array}{l}\text { The street is a narrow or wide linear element, mainly used for circulation, sometimes supported by } \\
\text { different activities, surrounded by buildings in residential areas [21]. }\end{array}$ & $\begin{array}{l}\text { Supported by different } \\
\text { activities }\end{array}$ \\
\hline $\begin{array}{l}\text { In all civilizations, streets have been the most widely used public space, with neighborhood commercial } \\
\text { streets and bazaars being the most popular [27] }\end{array}$ & public spaces of the city \\
\hline $\begin{array}{l}\text { Streets are elements that have an important role in the landscape of everyday life. People use the street as } \\
\text { a social place for transportation, travel, shopping or interaction with other people [17]. }\end{array}$ & $\begin{array}{l}\text { transportation, } \\
\text { shopping, social }\end{array}$ \\
\hline $\begin{array}{l}\text { The streets have a more important feature than their physical location in the city, their binding or } \\
\text { functional features. It is the people-oriented approach of streets that determines the reason why these } \\
\text { streets are preferred by people [10]. }\end{array}$ & $\begin{array}{l}\text { Physical and functional } \\
\text { properties }\end{array}$ \\
\hline
\end{tabular}




\section{Coastal Zone}

Coastal zones always command people's attention because of their natural features. Coasts are facing construction and environmental problems arising from the development of areas such as urbanization, industrialization, tourism, trade, natural resources, waste disposal and food [12]. Harbors, one of the important elements of economic mobility in Coastal zone, constitute the most important infrastructure of maritime trade. Parallel to the increase in maritime trade and ship sizes, the functions of the ports have also been diversified. The commercial ports in this diversity form a most important part and element of world trade today. The good exchange in the world occurs through these harbors [12]. It requires that each coastal place should be used in the balance of protection and usage by emphasizing its characteristics [4].

Coasts remain dynamic structures under the influence of natural forces. The threat of storms, hurricanes and artificial life threatens coastal settlements. The storms in the coastal, regions coastal soils and vegetation due to erosion caused by increased wave energy and saltwater flow to the inner wetlands as a result of sea swell [9]. Although coasts are used in various ways by societies, their broadest use is for purposes like maritime trade, tourism and fishing. Ships and small boats (yachts, fishing boats, etc.) used to carry out these activities to look for areas protected against the effects of the waves and current [12].

\section{Research Area}

To illustrate work, Bagdat Street of Istanbul was chosen. It was restructured based on its historical, social activities as a street. Bagdat Street is the most important of the main transportation axes starting from Kiziltoprak to Maltepe within the borders of Kadikoy District on the Anatolian Side. In the west, it connects from Kiziltoprak to the Bosphorus Bridge, and in the east, the street that runs parallel to the beach to Bostanci, crosses the railroad and passes to the north of the railway to Maltepe (Figure 1).

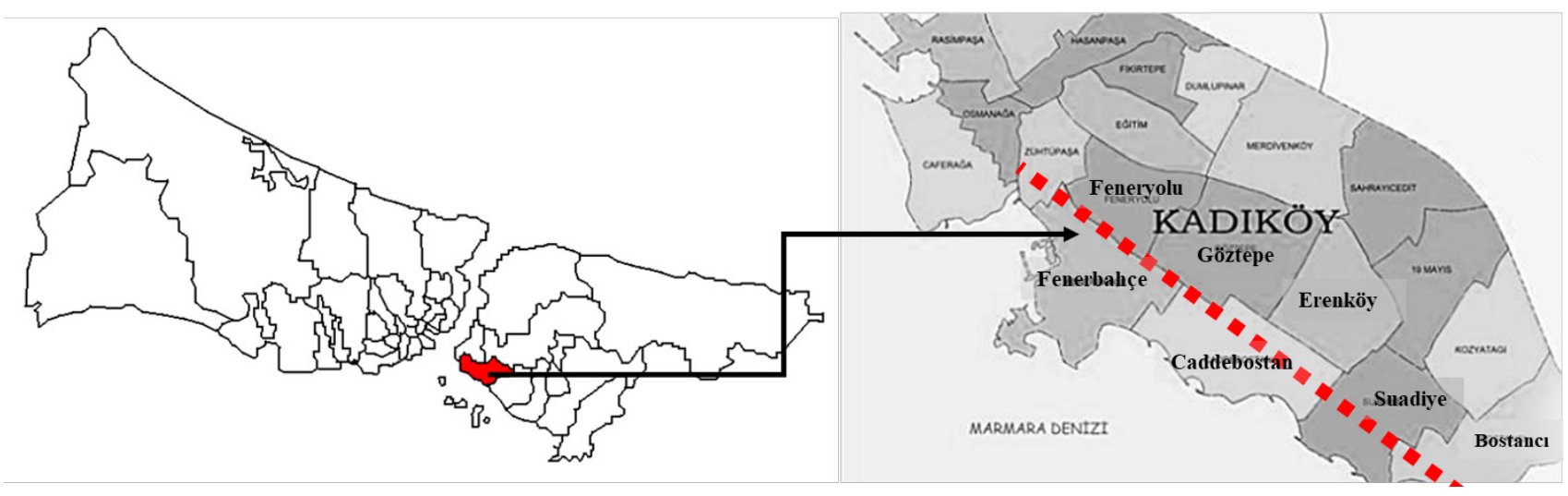

Figure 1. Bagdat Street Location 


\subsection{Methodology}

In this research, data have been collected through documentation and surveying using questionnaires. Data were analyzed using descriptive and inferential statistics. Data collection first started with observations; what the users did when they came to the street, why they came to the street and the hours and days the street was busier were observed. Also, photos of Bagdat Street were taken on different days and times and a survey was conducted with users around Bagdat Street. During the survey, 250 individuals were interviewed one by one on different days and periods (Table 2).

Table 2. Distribution of Respondents for Sample Area

\begin{tabular}{|c|c|c|}
\hline Background & $\begin{array}{c}\text { Number of } \\
\text { participants }\end{array}$ & $\begin{array}{c}\text { Total number of } \\
\text { participants }\end{array}$ \\
\hline Gender: & 163 & 250 \\
Female & 87 & \\
Male & & \\
Age: & - & 250 \\
Less than 18 & 64 & \\
$18-24$ & 127 & \\
$24-60$ & 59 & \\
above 60 & & \\
\hline
\end{tabular}

\section{Result}

\subsection{Physical Properties of Bagdat Street}

While examining the physical properties of Bagdat Street, the maps and aerial photographs on different dates were investigated firstly. Based on the historical approach, it was concluded that not only the physical traces of the Street were sufficient to investigate but also the processes of Bagdat Street. As in other districts of Istanbul, the period of the urbanization process with regards to the changes we have mentioned as the cause of physical changes on Bagdat Street and its vicinity was the fastest with the addition of the Bosphorus Bridge in the first half of the 1970s. The bridge, which is shown as a solution to traffic and Bosphorus crossings, has affected the entire life and social structure of the Anatolian Side. Two-floor houses and pavilions in green areas were demolished and apartment buildings were built in their places, while 4.5-floor apartments were turned into 12-13-floor blocks [11]. In Table 3 and Figure2, the historical process of Bagdat Street was analyzed:

Table 3. Bagdat Street Historical Development Timeline (Arı, 1994., Tekeli, 1994., Pekşen, 2015., Yazıcıŏlu, 2010, Berkmen \& Turgut, 2019)

\begin{tabular}{|c|c|}
\hline \multicolumn{2}{|c|}{ History } \\
\hline 1873 & $\begin{array}{l}\text { With the commissioning of the railway, it is seen that settlements around the stations located in the north of Bagdat Street } \\
\text { and the neighborhoods began to form with the emergence of commercial cores. }\end{array}$ \\
\hline 1930 & $\begin{array}{l}\text { Mustafa Guler has had Suadiye Beach built, and with the formation of these new beaches on the coast, the shores of the } \\
\text { Anatolian side have turned into a summer resort for families from big cities such as Ankara and Izmir. }\end{array}$ \\
\hline 1935 & $\begin{array}{l}\text { Tramlines have been passed on both sides of the street. While these tramlines initially had separate roads, after 1940, the } \\
\text { rails were lowered to the street level and the traffic road was made more spacious to expand Bagdat Street. The plots on } \\
\text { both sides of the street were divided into small parcels after } 1935 \text { and two-floor small villas were built. }\end{array}$ \\
\hline 1950 & $\begin{array}{l}\text { It is seen that two important developments affected the life and appearance of Kadıköy in the } 1950 \mathrm{~s} \text {. The first is the } \\
\text { formation of slums caused by the rapid urbanization process in Turkey; the second one is the Menderes operations. After } \\
\text { 1950, large mansions and villas were demolished and stone buildings with gardens were built instead. }\end{array}$ \\
\hline 1958 & As the tramlines were completely removed, the street was closed to traffic for months and then expanded again. \\
\hline 1970 & $\begin{array}{l}\text { These geometrical layouts were made to increase the diversity of the façade and the search for different textures is almost } \\
\text { like reflections of the basic design discipline. }\end{array}$ \\
\hline $\begin{array}{l}1980 \\
- \\
1990\end{array}$ & $\begin{array}{l}\text { With the economic policies and practices between the years, the income level increased, and the foreign chain stores and } \\
\text { the additional functions they brought together, the buildings lost their residential properties and the ground and first floors } \\
\text { became shops, stores, offices. Moving the trade to the ground and first floors brought up billboards, which caused visual } \\
\text { pollution. }\end{array}$ \\
\hline 1999 & $\begin{array}{l}\text { After the earthquake, closed housing areas started to form on the Anatolian side north of Bagdat Street, parallel to FSM } \\
\text { Bridge connection roads. }\end{array}$ \\
\hline 2000 & Increased construction (bars and local restaurants) \\
\hline 2012 & Rapid Urban Expansion and population growth \\
\hline 2017 & increase of land prices, high-rise construction and introduction of new laws on the region's urban development \\
\hline
\end{tabular}




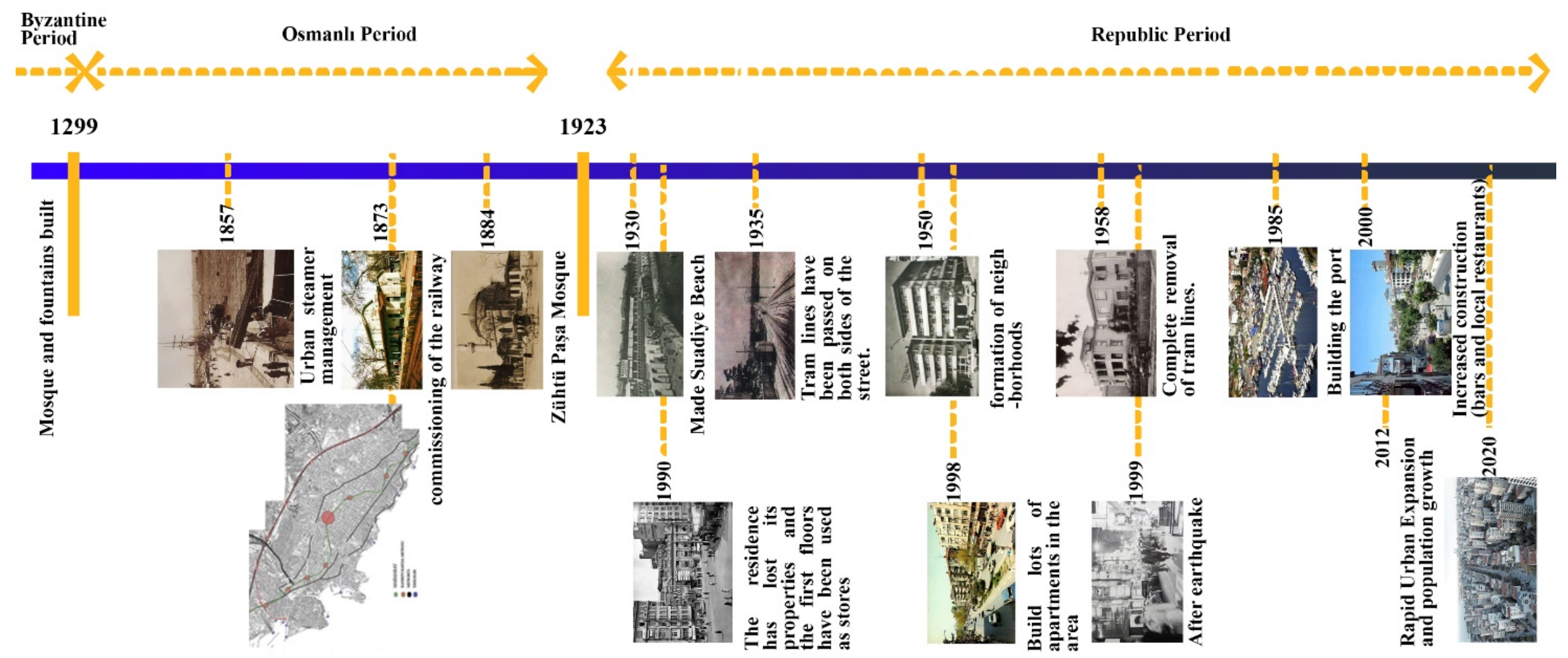

Figure 2. Bagdat Street Time line 
In the questionnaire, the answers provided with the question "What kind of physical purposes do people use Bagdat Street for?" were in general;

- I shop on Bağdat Street

- I visit Bağdat Street for general purposes (market, transportation, work, school, health facilities, law offices, etc.).

- I go to Bağdat Street for sightseeing.

- I commute through Bağdat Street.

According to the survey results, $81 \%$ of women and $76.2 \%$ of men shop on Bağdat Street, $75 \%$ of women and $65.2 \%$ of men visit for general purpose, $48 \%$ of women and $53.6 \%$ of men go for sightseeing and $62.5 \%$ of women and $72 \%$ of men commute through it; thus, women use the street more for shopping. The primary reason for this is the presence of famous major brands in the region (Figure 3).

Respondents answered the question of "How do people find the visual quality of Bagdat Street?"

- Bagdat Street is clean and well-maintained.

- Visual quality of Bagdat Street is impressive.
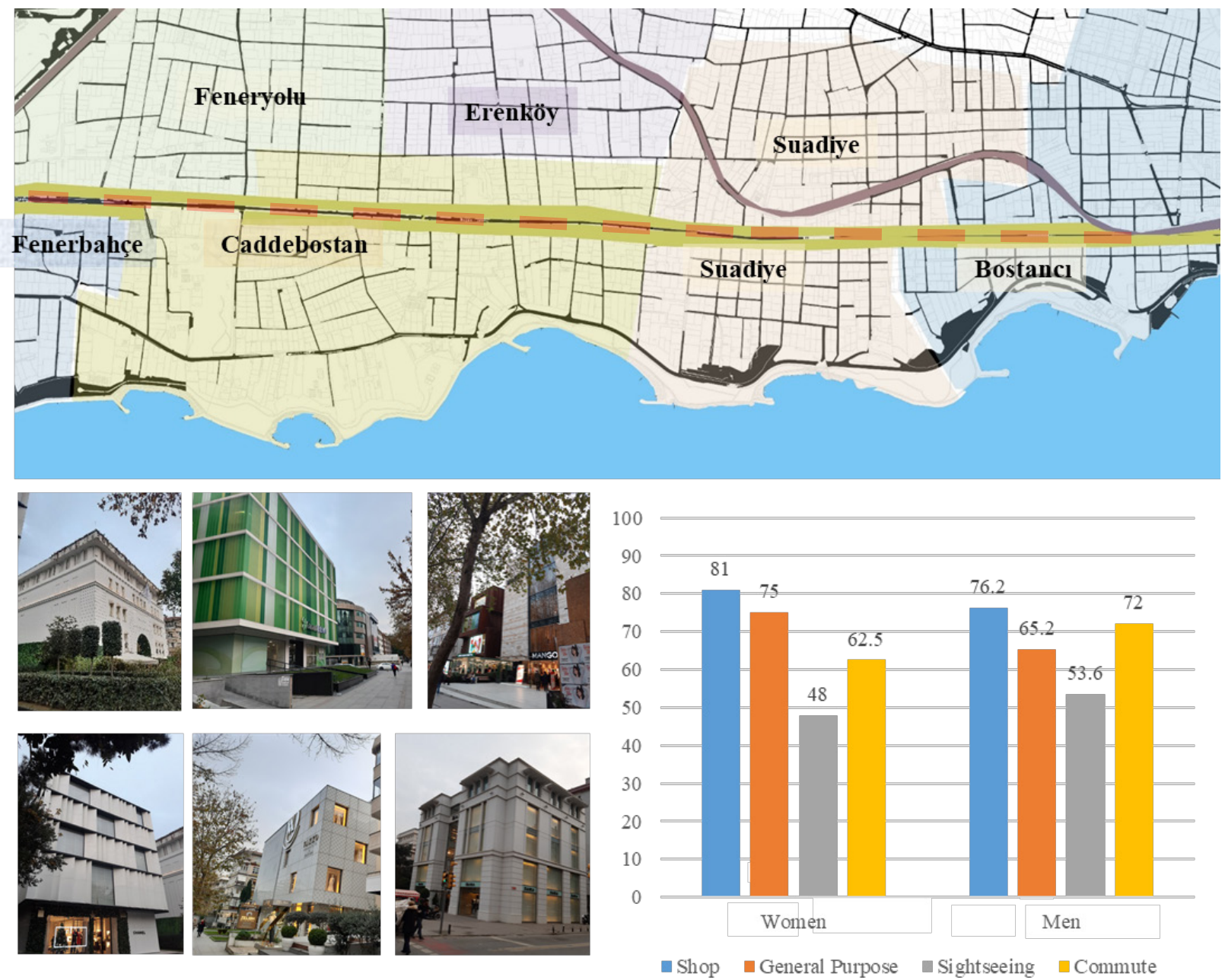

Figure 3. Which purposes do people use Bagdat Street for?
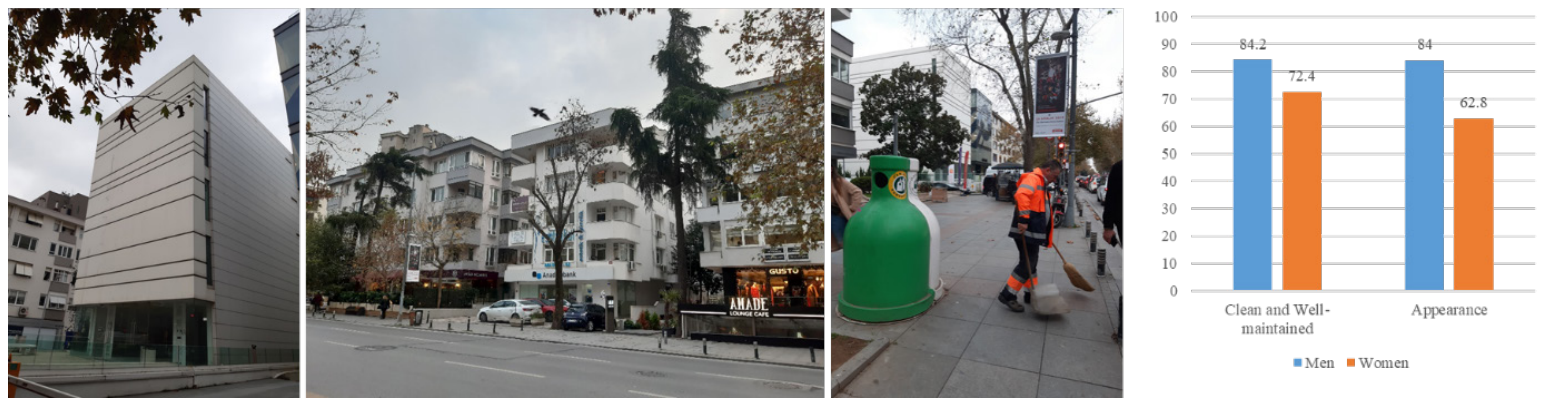

Figure 4. About the Form of the Buildings in Bagdat Street and Analysis of Visual Quality 
According to the results of the survey, $84.2 \%$ of men and $72.4 \%$ of women find the street clean and well-maintained. $72.4 \%$ of men and $62.8 \%$ of women like its appearance (Figure 4 ). Though, the types of materials and store signs used on the facades seem to reduce its visual quality. Other parameters of the street are analyzed as in the table below:

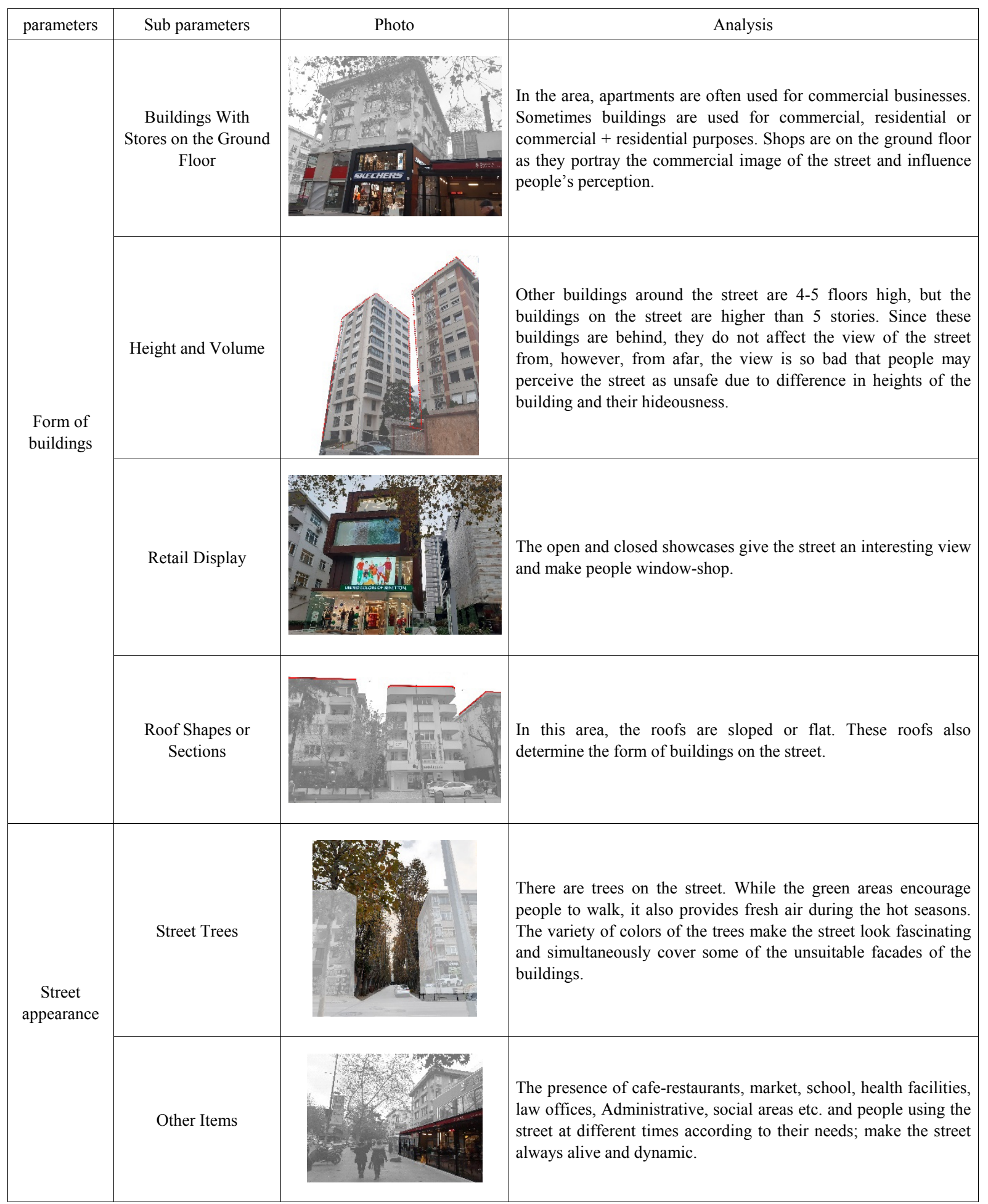




\subsection{Functional Features of Bagdat Street}

The streets, one of the most important parts of public space, affect our lives both at the functional level, and how we reach one another and public authorities [27]. In addition to the technical requirements necessary to make urban space functional, public space is expected to be attractive, safe and well-maintained. Financial resources and good organization are needed to achieve this. In daily life activities, the cleanliness, accessibility, attractiveness, comfort, vitality, functionality, safety and design elements of the space are questioned [27].

- Privacy

- Transportation

- Social Relationship

6.2.1. Privacy:

Cities are places where communities and individuals come to interact with one another, which take the role of a meeting place for different sections of the society, where people from all walks of life come together [8]. Take a look at the building structures on Bagdat Street today, it is seen that there are residential, residential/commercial and commercial land uses. In line with the changing living conditions and consumption habits, it is remarkable that the buildings have turned into business. Newman divides urban spaces into public and private spaces. While public spaces are spaces belonging to the common use of society, private spaces are spaces for individual use [18]. There are areas where public and private outdoor spaces overlap and intersect each other. These intersections are usually semi-public and semi-private areas. In the following section, there are public, semi-public, private and semi-private areas on Bagdat Street (Figure 5,6).

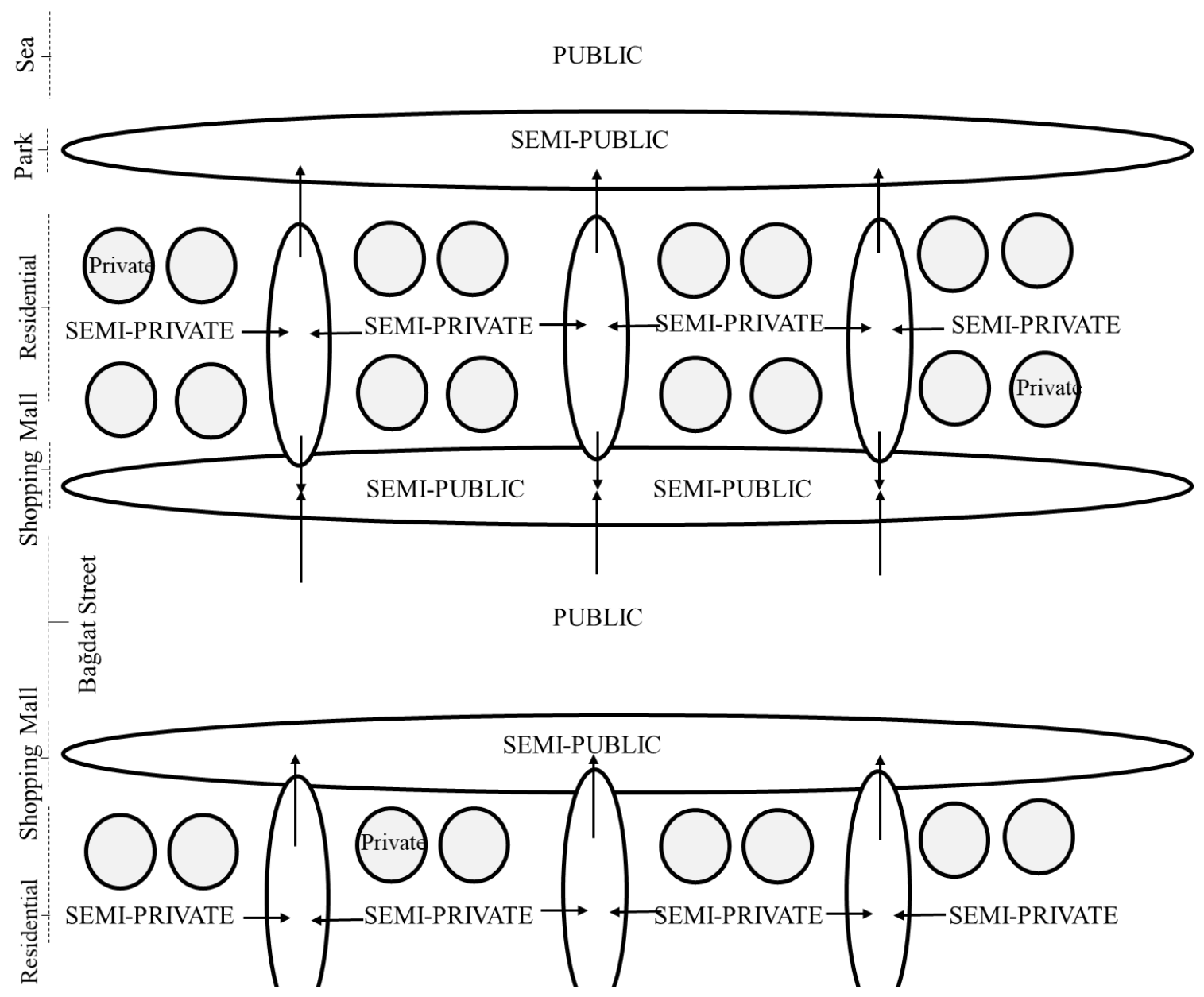

Figure 5. Privacy of Bagdat Street 


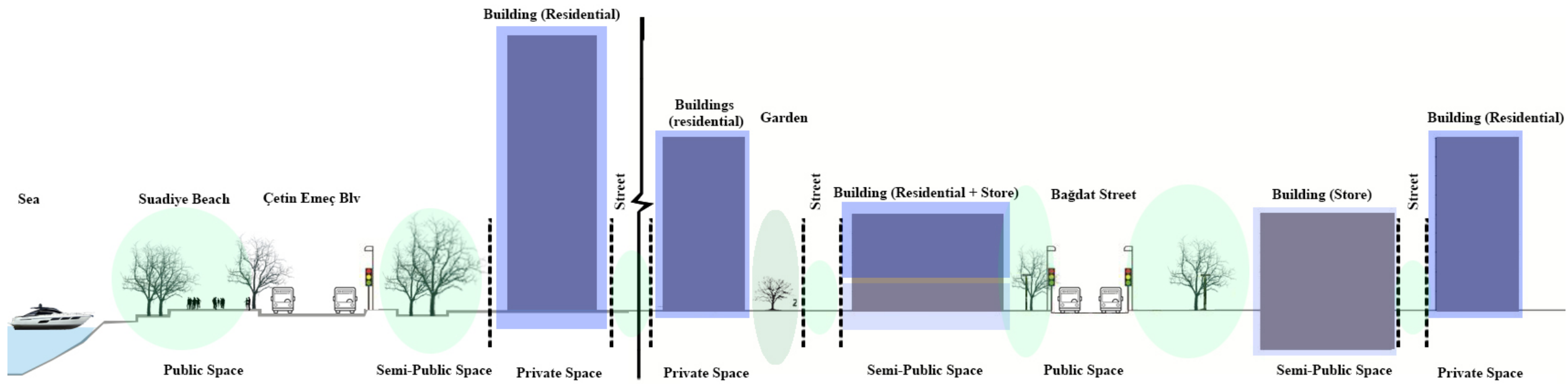

Figure 6. Cross Section of Bagdat Street 


\subsubsection{Transportation}

In this survey, the suitability of this region for children, pregnant women, the elderly and the disabled was investigated. According to the result, Bagdat Street should be more suitable for the groups using this place.
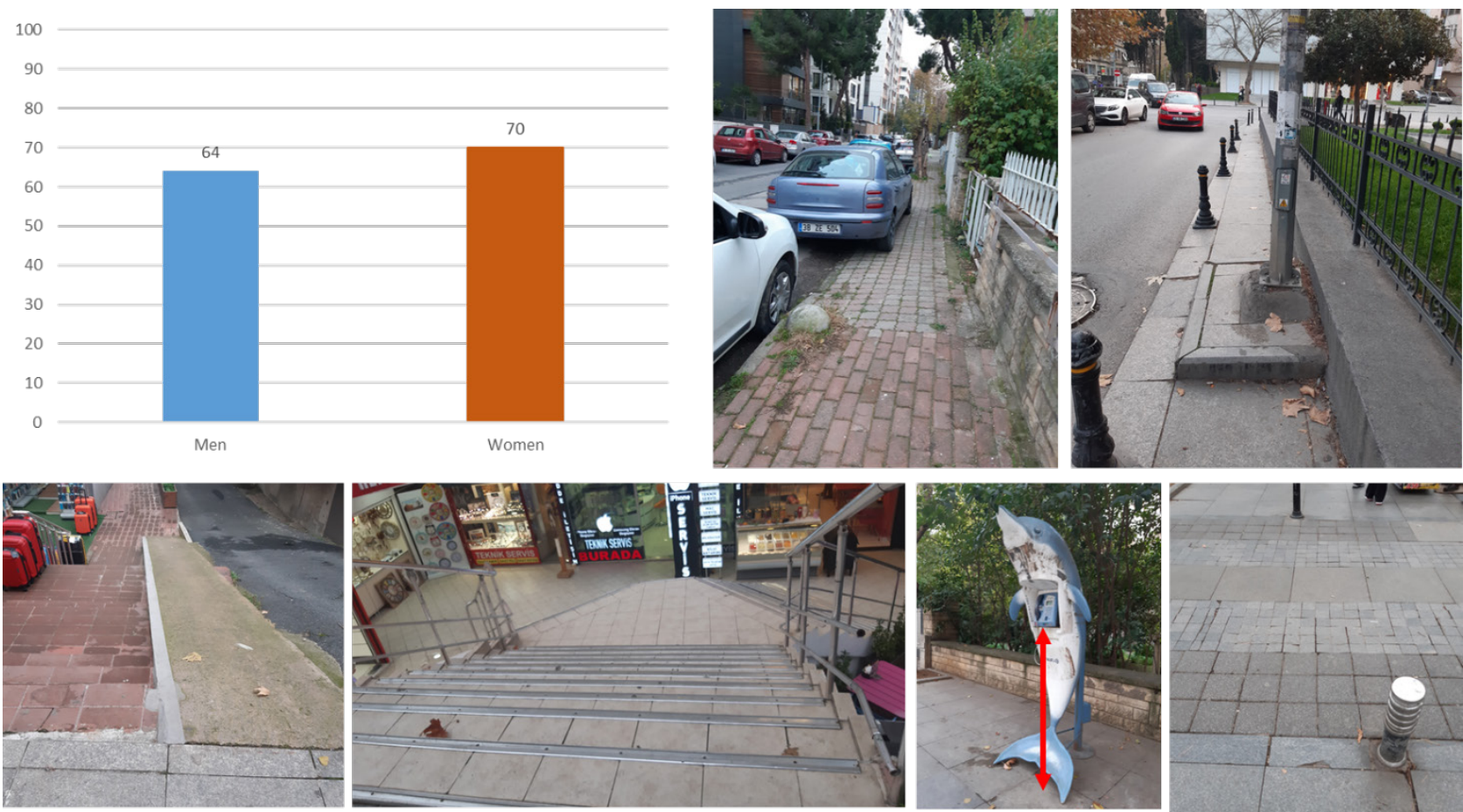

Figure 7. The Suitability of Street for Different Group of People

The sidewalks are high and narrow and the slope of the ramps is not suitable. For the use of strollers, $70 \%$ of women and $64 \%$ of men face problem (Figure 7 ).

\subsubsection{Social Relationship:}

When asked "What purposes do users use Bagdat Street for?" answers provided include

- Bagdat Street is used to organize cultural events.

- $\quad$ Bagdat Street is used for physical activities (sports, walking)

- $\quad$ Bagdat Street is used for social activities (Figure 8).
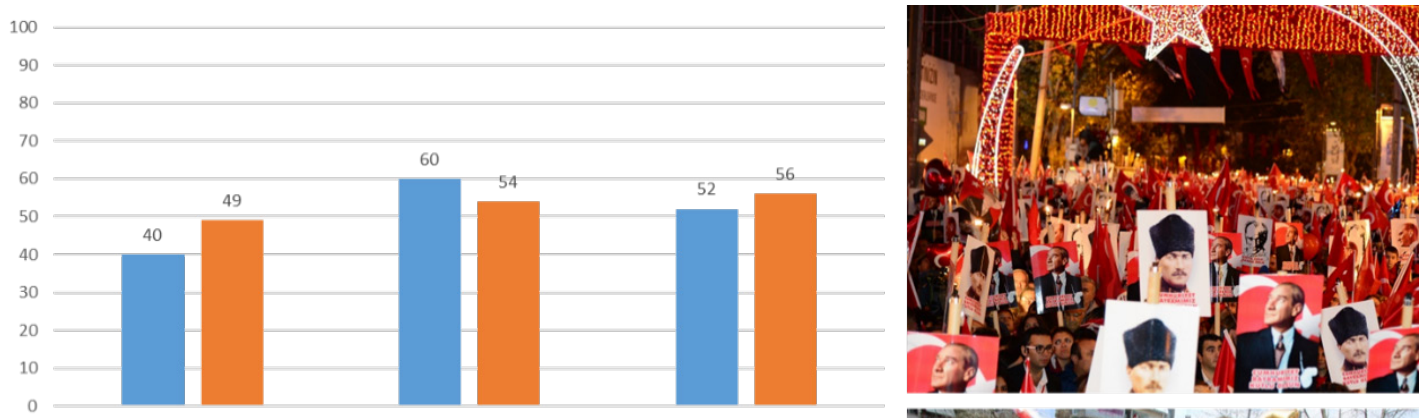

Cultural activities

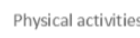

Social activities

n Male $=$ Female
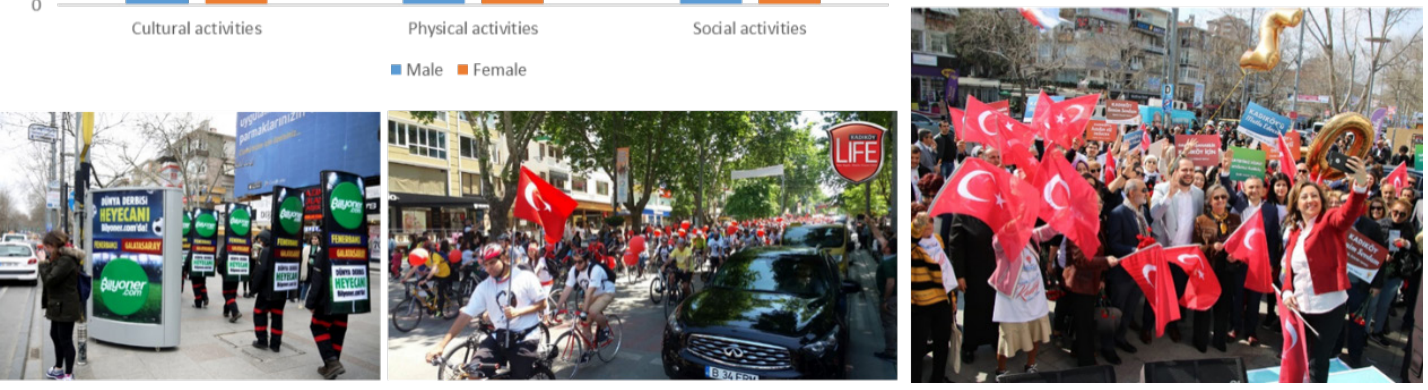

Figure 8. Which Purposes the Bagdat Street Is Used for? [28,29,30,31] 


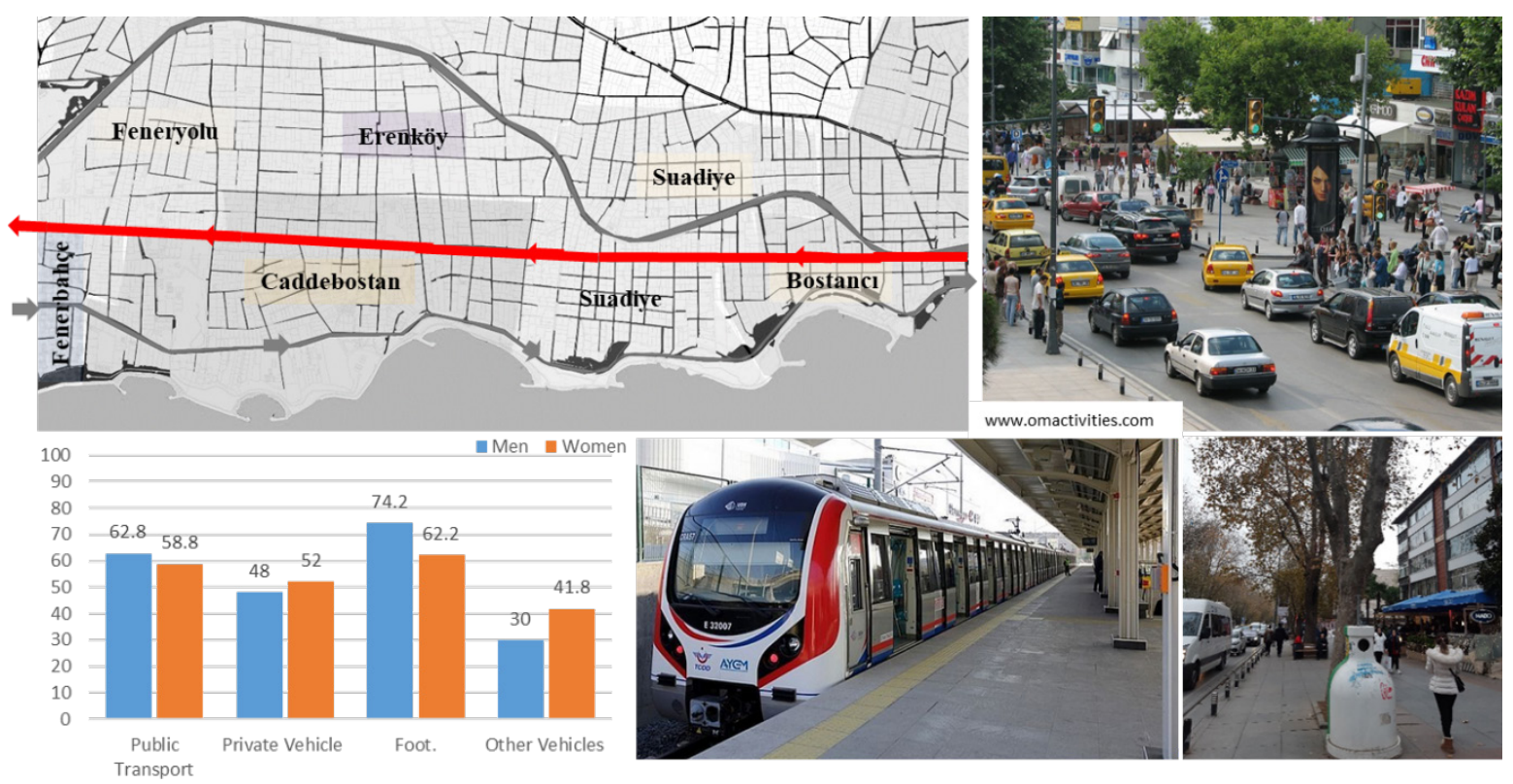

Figure 9. Accessibility of Bagdad Street

In the questionnaire, 4 responses were provided with the question "How do the users reach Bagdat Street?";

- $\quad$ by public transport.

- $\quad$ by private vehicle (automobile, motorcycle).

- by foot.

- $\quad$ by other vehicles (bicycles, scooters, etc.).

In addition to private vehicles, many public transport such as metro and bus are preferred to reach the Bagdat Street, while the metro is more preferred because there are no traffic problems. According to the results of the survey, $62.8 \%$ of men and $58.8 \%$ of women use public transport, $48 \%$ of women and $52 \%$ of men use private vehicles, $30 \%$ of women and $41.8 \%$ of men use other vehicles (bicycles, scooters etc.). When not preferring transportation, $74.2 \%$ of women and $62.2 \%$ of men prefer to go on foot because of the ease of access (Figure 9).

\section{Conclusions}

Bagdat Street is one of the most important streets in the Asian part of Istanbul, where there have been physical and functional changes throughout history. This article examined the parameters of the region and analyzed its results. This article addressed the Suadiye region of Bagdat Street, according to the data obtained in the field research, each building and store has its own unique facade and appearance in their unique architecture. The fact that the buildings are very close to each other complicates the view of the street. A variety of decorations applied on facades to attract attentions, resulted in a visual chaos are shown in Figure 10.

According to the survey results, Bagdat Street has undergone many physical changes throughout history. Due to the physical change occurring in this region, the locals who have lived here for ages no longer feel that they belong to this place or have been completely alienated here. The Suadiye region is used not only by the locals of the region, but also by outsiders who come to the region for various purposes, such as shopping and social interactions. The fact that the green areas in the region are high and that there are beautiful areas to walk on the beach makes the region attractive to visitors. At the same time, ease of access and public transport are other factors that make the region attractive. Adequate lighting, vast number of shops and crowded roads make this region perceived to be safe. The streets, on the other hand, give the feeling that the area is unsafe due to the high buildings, and desolation. 


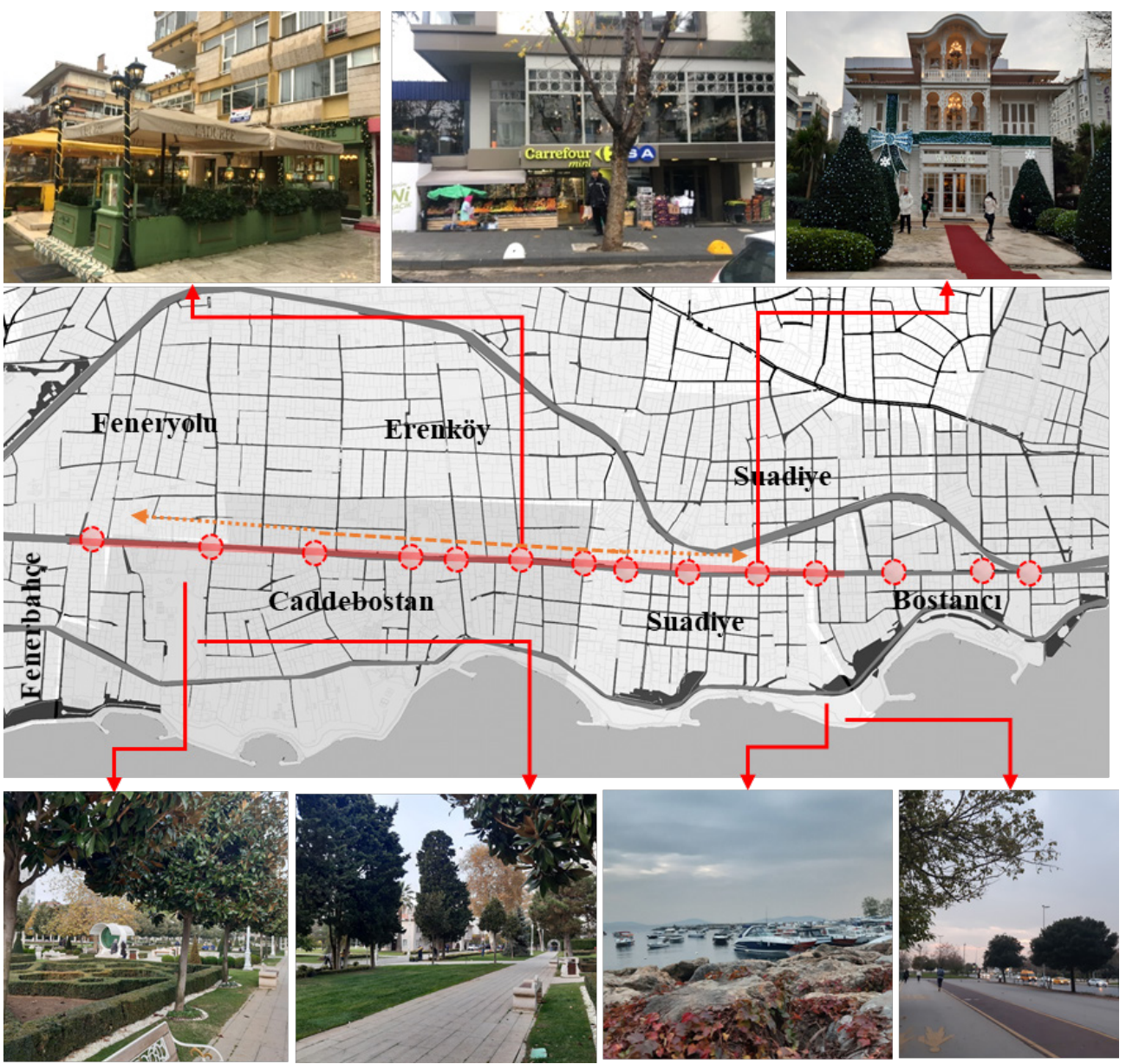

Figure 10. Facades on Bagdat Street

Tabibian, Tehran, Tehran University Publication, 1998.

[8] M. E. Erdönmez, A. Ak1, Effects of Open Public Urban Spaces in Social Relations, Megaron, 1: 67-87, 2005.

\section{REFERENCES}

[1] H. Arl, Effects of Economic and Social Developments on Housing Units in the Process of Housing, Doctoral Thesis, University of Istanbul Technic, Turkey, 1994.

[2] C. Alexander, M. Silverstein, S. Ishikawa, A Pattern Language, Oxford University Press, New York, 1977.

[3] F. Attar1, m. E. Mazhar, Identifying and analyzing effective factors on the role of public space in sustainability of urban environment, Cumhuriyet University Faculty of Science Science Journal, 36 (6): 539- 652, 2015.

[4] A. Bagc1, Integrated Coastal Zone Management of Antalya-Lara as A Model, Master Thesis, University of Istanbul, Turkey,2007

[5] N.H. Berkmen, S. Turgut, "Bağdat Street" in the Grip of Urban Transformation "Bağdat Street" in the Grip of Urban Transformation, Megaron ,14(SUPPL. 1):155-166, 2019

[6] S. Carr, M. Francis, L. Rivlin, A. Stone, Public Space, Cambridge University Press, Cambridge, 1992.

[7] C, Gordon, "Selection of City's View", Manouchehr
[9] J.Duxbury., S, Dickinson. Principles for Sustainable Governance of the Coastal Zone: In the Context of Coastal Disasters, Ecological Economics 63(2-3):319-330, 2007.

[10] A. Jacobs, Great Streets, The MIT Press,1996

[11] S. Kizildere, Reconstruction movements and sampling of Bagdat Street during the metropolitanization of Istanbul. Master thesis, University of Y1ldiz Technic, Turkey, 1989.

[12] Ö. K1lıçöz, Coastal zone management and the sample area of coastal structures Tekirdag Port, Master Thesis, Integrated Coastal Zone Management, Tekirdağ, Turkey, 2009.

[13] M. Harirchian., M. Esmaeili., S, Kermanshahi, A new perspective on urban street design, Conference: The Transportation Research Board (TRB) 97th Annual Meeting, 2019.

[14] A. Lotfata, A. Ataöv, Urban streets and urban social sustainability: a case study on Bagdat street in Kadikoy, Istanbul, Journal European Planning Studies, 27(7): 1-21, 2019.

[15] A, Lotfata, the role of sociocultural practices in the transformation and re-structuring of streets: a case study of bağdat street in Istanbul, $\mathrm{PhD}$ thesis, Middle East 
Technical University, 2014.

[16] A. Madanipour, why are the design and development of public spaces significant for cities, Journal Environment and Planning B: Planning and Design, 26(6): 879-891, 1999.

[17] C. Marcus-Cooper, C. Francis, People places: design guidelines for urban open space, John Wiley Son, New York, 1998.

[18] O. Newman, Defensible Space: People and Design in the Violent City, Architectural Press, London, 1972.

[19] C. Pekșen, Street as A Publıc Space: Case Study Bagdat Street, Master Thesis, University of Yildiz Teknik, Turkey, 2015.

[20] Pakzad, Jahanshah, Identity and Identity of Space, Saffeh Journal, No. 21, Tehran, 1996.

[21] A. Rapaport, History and Precedent in Environmental Design, Plenum Press, New York, 1990

[22] A. Smithson, P. Smithson, Urban Structuring, Studio Vista, London, 1967.

[23] I. Tekeli, The Development of the İstanbul Metropolitan Area, Kent Basımevi, İstanbul, 1994.

[24] F. Tibbalds, Making people friendly towns: Improving the public environments in towns and cities, Longman Press, Harlow, Essex, 1992.

[25] S. Velioğlu, A Model for Assessing Physical Formation in Architectural Scale Based on Outdoor Life, Doctoral Thesis, University of Mimar Sinan Fine Arts, Turkey, 1990

[26] S. Brower.Good neighborhoods. Westport, CT: Praeger. 1996

[27] Z. Yazıcıoğlu Halu, Spatial Characteristics of Streets as Walkable Urban Spaces, Bagdat Street Case Study, Doctoral Thesis, University of Istanbul Technic, Turkey, 2010.

[28] http://www.alternatifreklamcilik.com.tr

[29] https://www.kadikoylife.com/bagdat-caddesisnde-lansmanetkinlikleri\%C2\%85/

[30] http://www.ozgulozkanyavuz.com/dunya-mutluluk-gunu-et kinlikleri-faaliyetleri.html

[31] http://www.gazetekadikoy.com.tr/gundem/kadikoy-de-cum huriyet-coskusu-h13106.html

[32] http://www.omactivities.com/2012/09/bagdat-caddesi-kadk oy-bostanc-ulasm.html 